\title{
sciendo
}

CIVIL AND ENVIRONMENTAL ENGINEERING REPORTS

E-ISSN 2450-8594

CEER 2019; 29 (1): 092-101

DOI: $10.2478 /$ ceer-2019-0007

Original Research Article

\section{CHANGES TO WATER QUALITY IN THE WATER SUPPLY NETWORK OF ZIELONA GÓRA}

\author{
Anita JAKUBASZEK ${ }^{1}$, Justyna MOSSETTY ${ }^{2}$ \\ University of Zielona Góra, Zielona Góra, Poland
}

\begin{abstract}
The article presents physiochemical parameter changes in water supply network of Zielona Góra. On the basis of the obtained test results, the impact of prolonged retention of water in the network on its quality was determined, at the measuring points located on the territory of Zielona Góra.

It was shown that together with an increase in distance of measuring points from Water Treatment Plant, content of mainly iron, turbidity and colour increased too. In the results analysis, it was determined that retention time and water distribution are the most significant factors in the network contributing to deterioration of water quality at measuring points.
\end{abstract}

Keywords: water quality, secondary contamination of water, water supply network

\section{INTRODUCTION}

During the transport of network water in the distribution system, both values of physiochemical composition indicators can change as well as the bacteriological quality $[3,4,7]$.

Main causes of secondary contamination include lack of chemical and biological stability of water put into distribution, improperly conducted disinfection of

\footnotetext{
${ }^{1}$ Corresponding author: University of Zielona Gora, Institute of Environmental Engineering, Szafrana st 15, 65-246 Zielona Góra, Poland; e-mail: a.jakubaszek@iis.uz.zgora.pl, tel. +48683282396

2 Student of the University of Zielona Góra, Poland
} 
water, and changeable hydraulic conditions occurring in the network (water flow rate, pressure) [1,9].

Lack of chemical stability leads to corrosiveness of the material (water aggressivity) or to sedimentation, mainly of calcium carbonate. Corrosion of iron pipes contributes to accumulation of iron particles in the network. Moreover, metals are used as coagulants in sewage treatment plants in order to eliminate organic matter, and their trace content can pass to distribution system and settle on the pipes. Excessive presence of these metals in drinking water can cause colouration of the water and / or changes in taste [2,5].

Lack of biological stability is caused by the presence of non-organic and organic nutrients in the water, which condition the secondary growth of micro-organisms on the inner walls of the pipe system (i.e. nitrogen and phosphorus compounds, and biodegradable organic compounds) [6]. Development of micro-organisms in the network increases the factor of water contamination with organic substances, contributes to increase of colouration and turbidity and undesired taste or smell [9]. If the distribution system contains biological sedimentation, then changes in the content of organic substances are asserted. Biofilms constitute a source of secondary organic contamination, while heterotrophic micro-organisms use biodegradable, and mainly digestible organic carbon. Increase in the level of organic contamination of water is caused by the products of metabolic turnover of micro-organisms released to the water and the dead biomass, and sometimes also components of the synthetic installation materials [4].

Secondary water contamination also depends on the pressure and water flow rate in pipe networks. Low water flow rate contributes to sedimentation of solid particles on the surface of pipe networks and extends the time of water retention in the network. Together with the extended water retention time in the distribution system, there is an observable deterioration of water quality caused by decline of disinfecting agent which creates conditions for secondary development of microorganisms and the risk of bacteriological contamination of water. Highly increased velocity of water contributes to flushing out of chemical and biological sediments into the water. High pressure increases failure frequency of water supply connections (macropores emerge), and consequently there is loss of water in the network, while insufficient pressure can cause invasion of external contamination, i.e. withdrawal of water from internal installations $[4,6]$.

Prevention of secondary water contamination in the distribution system is one of the most difficult technical problems. Priority of each facility providing water is to ensure continuous production, distribution and delivery of water with appropriate pressure, required efficiency and the best possible bacteriological and physiochemical parameters [10]. In addition to ensuring chemical and biological stability of water introduced into the water supply network, it is also important to 
care for a good technical and sanitary condition of the whole distribution system and of the containers storing water. The control of biofilm formation is maintained by disinfecting agent present in the whole distribution system. In case of vast water supply networks, it is recommended to disinfect in zones, which prevents undesirable changes of water quality in the water supply network. It is also important to remove sedimentation settled in water supply connections. Removal of sedimentation from the network is ensured by regular flushing of water supply network with water containing disinfecting agent or water and air. During the flushing of system of poor technical condition, it is necessary to use protective layers in order to eliminate the migration of secondary contamination into the water. It is also necessary to periodically clean and disinfect the "network" containers storing water. Another problem is the over-dimensioning of devices for water treatment and oversized pipe system diameters which results in a significantly lower flow of water in the water supply network. Slow flows in the distribution systems lead to corrosion and accumulation of micro-organisms in the network. During the exploitation of the distribution system, water pressure and flow rate should be measured, and failure frequency monitored $[3,4]$.

\section{MATERIAL AND METHODS}

The objective of the study was to evaluate the impact of water retention time in the water supply network on changes in physiochemical parameters at the measuring points located on the territory of Zielona Góra city.

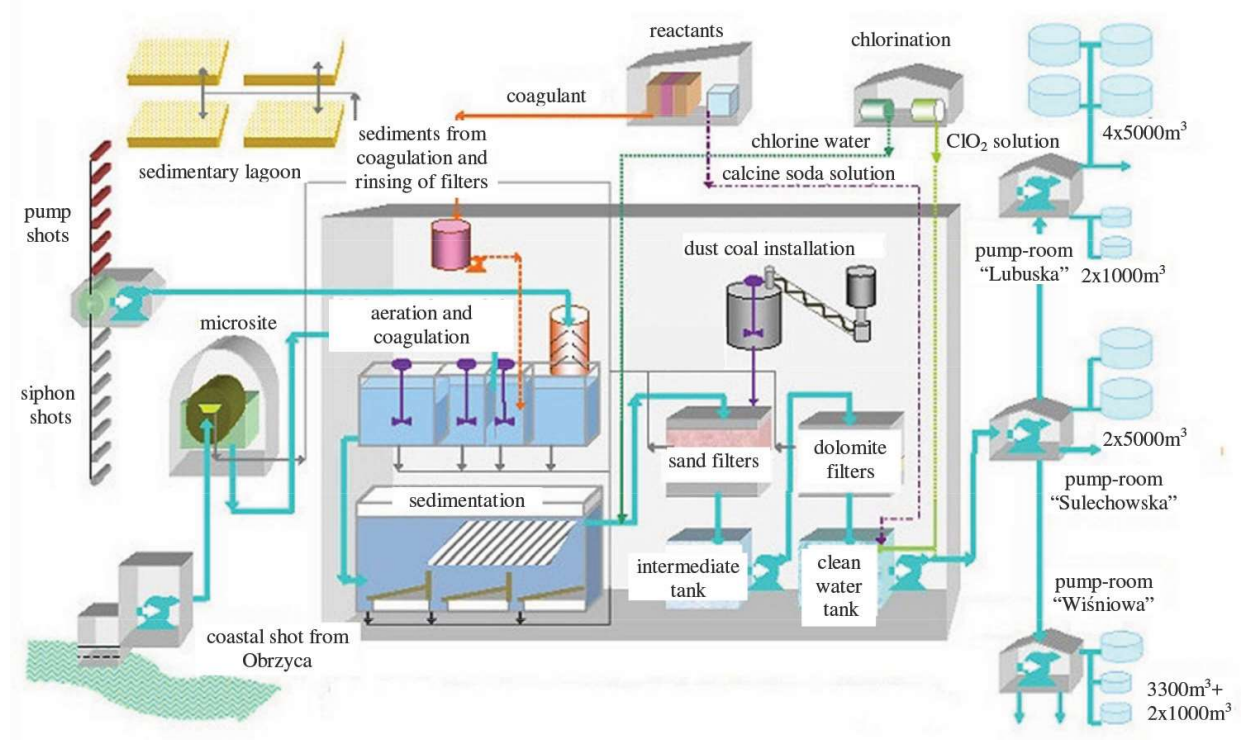

Fig. 1. Technological diagram of the Water Treatment Station in Zawada 
Water for domestic purposes of the residents is sourced from surface water intake on the Obrzyca river and ground water siphon intake. Average water intake from the river rangers from 12000 to $14000 \mathrm{~m}^{3} / \mathrm{d}$, whereas from ground waters from 8000 to $11000 \mathrm{~m}^{3} / \mathrm{d}$. The Water Treatment Plant in Zawada covers approx. 77\% of city water needs.

The water treatment process is carried out in the following technological sequence (Fig.1).

The surface water is subjected to the process of sieving through micro-sieves with $0.01 \mathrm{~mm}$ gaps. Ground water is aired in four cascades with forced air flow. In the chambers of fast mixing, mixing of surface and ground water takes place, and the coagulant polyaluminium chloride is dosed. Following the process of flocculation in the slow mixing chambers, water is directed to the vertical sedimentation tanks with separators in the form of lamella sets. The next stage of water treatment is filtration on open fast filters. The first stage of filtration is carried out on sand filters, the second takes place on dolomite filters. At the filtering plant water is additionally purified with active carbon dust dosed in the form of a suspension into the inflow chambers of fast filters. Then, water flows to the clean water tank where the disinfecting agent (chlorine dioxide) is dosed. The amount of water treated at the Water Treatment Plant in Zawada currently reaches circa 20000 $\mathrm{m}^{3} / \mathrm{d}$. There are 4 water pump houses within the territory of the city (Sulechowska, Lubuska, Braniborska and Wiśniowa pump houses) together with equalising tanks (joint capacity of drinking water tanks in the territory of the city reaches circa $40000 \mathrm{~m}^{3}$ ).

Technical condition of the water supply network is diverse. It mainly depends on the age and type of material used in the construction of the network. Up until mid1970s, pipelines were made of grey iron and steal. In the following years it was mostly asbestos cement, then PVC. From 1993 both water supply network as well as connections are made mainly from the PE-HD pipes. Currently, approx. 54\% of active water supply network is made of iron pipes.

Places of sourcing water samples for the analysis were selected in such a way so that further points would be located at a greater distance for the Water Treatment Plant.

8 measuring points were selected: 1 - Poznańska str, 2 - Sulechowska str, 3 Kasprowicza str, 4 - Jędrzychów, 5 - Kaspra Twardowskiego str, 6 - Ochla, 7 Kiełpin, 8 -Jarogniewice (Fig. 2). A significant factor behind choosing the points was water retention time in the network which took from 30 minutes to 10 hours (Tab.1). Water retention time in the water supply network was indicated in the EPANET software. 


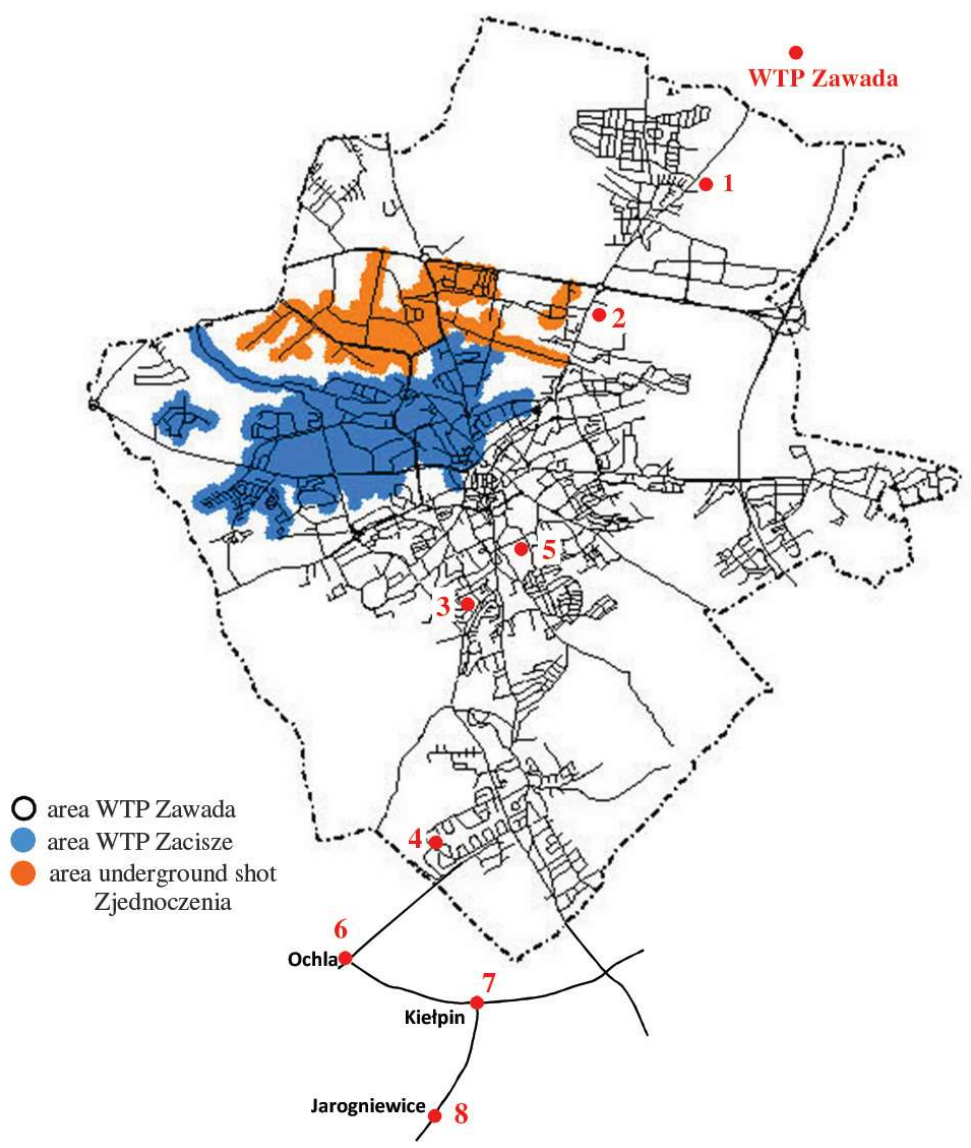

Fig. 2. Location of control points in the city

Water samples for tests were sourced from internal water supply installations on 18.12.2017 and 15.01.2018. The scope of laboratory analysis of water samples taken, includes the determination of parameters: $\mathrm{pH}$, colour, turbidity, $\mathrm{COD}_{\mathrm{Mn}}$, total iron and manganese. Water samples were collected according with the guidelines for the collection of water samples for laboratory tests (PN-ISO 56675: 2017-10).

\section{RESULTS AND DISSCUSION}

Together with the increase of distance between the Water Treatment Plant and measuring points, the water retention time in the water supply network was also extended from 30 minutes at the first point near Poznańska str to 10 hours in Jarogniewice (tab. 1). 
Table 1 . Water age at measuring point

\begin{tabular}{|c|c|c|}
\hline Control points & Distance from WTP (km) & Water age (h) \\
\hline P1 & 3.3 & 0.30 \\
\hline P2 & 2.2 & 0.35 \\
\hline P3 & 9.1 & 1.00 \\
\hline P4 & 15.9 & 3.0 \\
\hline P5 & 8.1 & 1.5 \\
\hline P6 & 17.6 & 8.0 \\
\hline P7 & 19.8 & 9.0 \\
\hline P8 & 23.9 & 10.0 \\
\hline
\end{tabular}

Table 2 presents the results of research on the quality of water parameters in the water supply network in Zielona Góra. The parameters of water injected into the water supply network were in accordance with the Regulation of the Minister of Health on the quality of water intended for human consumption (Journal of Laws 2017, item 2294) [8]. The average values of indices in the period of the conducted tests were respectively: the colour: $3.0 \mathrm{mgPt} / \mathrm{dm}^{3}$, turbidity $0.23 \mathrm{NTU}, \mathrm{COD}_{\mathrm{Mn}}$ value $2.17 \mathrm{mgO}_{2} / \mathrm{dm}^{3}$, the total iron $0.020 \mathrm{mgFe} / \mathrm{dm}^{3}$ and the $\mathrm{pH}$ ranged from 7.74 to 7.84 .

Table 2. Water parameters at control points in the water supply network

\begin{tabular}{|l|c|c|c|c|c|c|c|c|c|}
\hline \multirow{2}{*}{ Parameter } & \multicolumn{8}{|c|}{ Control points } \\
\cline { 2 - 10 } & WTP & P1 & P2 & P3 & P4 & P5 & P6 & P7 & P8 \\
\hline $\mathrm{pH}$ & $7.74-7.84$ & 7.86 & 7.58 & 7.60 & 7.56 & 7.57 & 7.58 & 7.45 & 7.59 \\
\hline $\begin{array}{c}\text { Colour } \\
\left(\mathrm{mgPt} / \mathrm{dm}^{3}\right)\end{array}$ & 3.00 & 3.00 & 3.00 & 4.5 & 8.25 & 6.75 & 14.25 & 18.75 & 19.50 \\
\hline $\begin{array}{c}\text { Turbidity } \\
(\mathrm{NTU})\end{array}$ & 0.23 & 0.39 & 0.40 & 0.42 & 0.52 & 0.49 & 0.57 & 0.65 & 0.80 \\
\hline $\begin{array}{c}\mathrm{COD}_{\mathrm{Mn}} \\
\left(\mathrm{mgO}_{2} / \mathrm{dm}^{3}\right)\end{array}$ & 2.17 & 0.50 & 4.00 & 2.60 & 2.90 & 3.40 & 0.40 & 0.20 & 3.30 \\
\hline $\begin{array}{c}\text { Total iron } \\
\left(\mathrm{mgFe} / \mathrm{dm}^{3}\right)\end{array}$ & $<0.020$ & 0.031 & 0.040 & 0.042 & 0.055 & 0.050 & 0.061 & 0.067 & 0.086 \\
\hline $\begin{array}{c}\text { Manganese } \\
\left(\mathrm{mgMn} / \mathrm{dm}^{3}\right)\end{array}$ & $<0.05$ & $<0.05$ & $<0.05$ & $<0.05$ & $<0.05$ & $<0.05$ & $<0.05$ & $<0.05$ & $<0.05$ \\
\hline
\end{tabular}

Together with the increase of water retention in the distribution network, values of colouration signify cantly increased especially at the last three measuring points (Fig. 3). Colouration of the water tested at the Water Treatment Station in Zawada was $3 \mathrm{mgPt} / \mathrm{dm}^{3}$, whereas in water samples sources in Kełpin and Jarogniewice the colouration values were above the permissible value $15 \mathrm{mgPt} / \mathrm{dm}^{3}$ and reached respectively $18.75 \mathrm{mgPt} / \mathrm{dm}^{3}$ and $19.5 \mathrm{mgPt} / \mathrm{dm}^{3}$. 


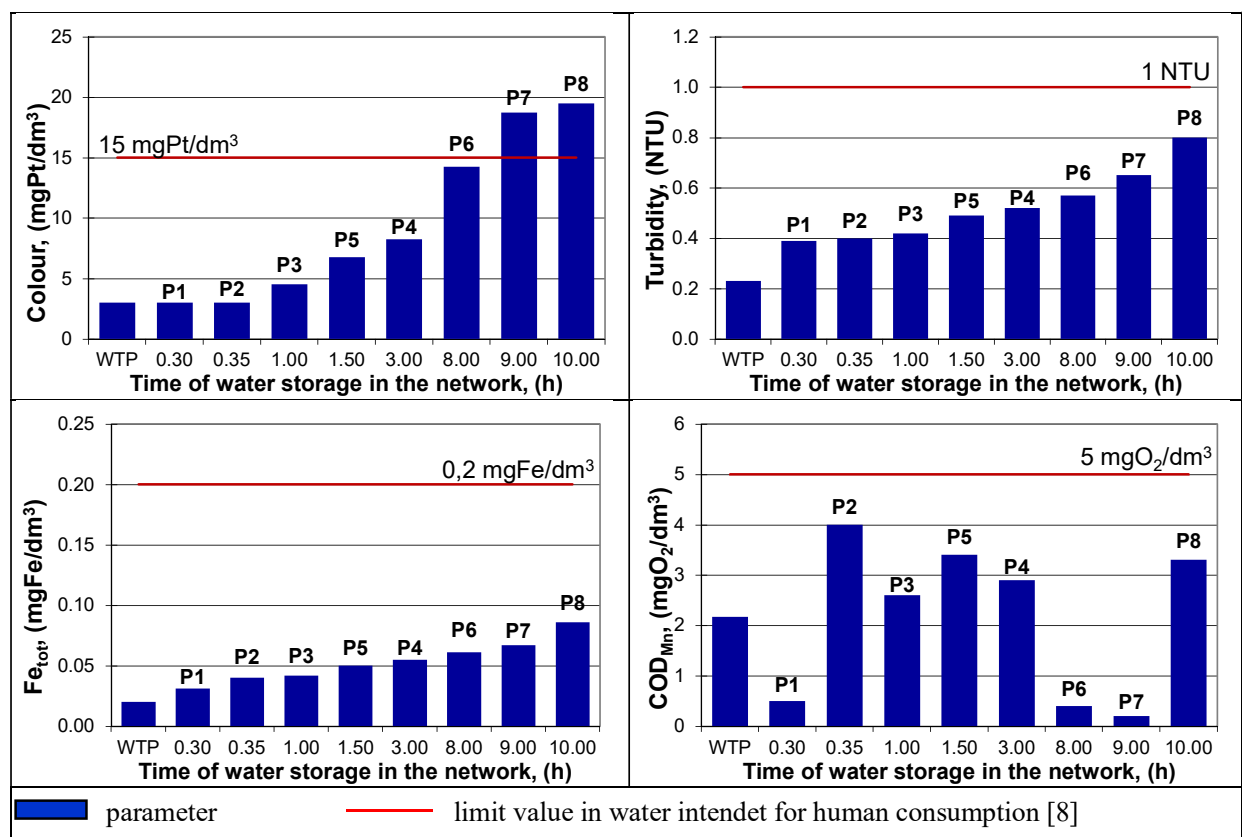

Fig. 3. Water parameters in the water supply network

Time of water retention in the distribution system also had an impact of the content of turbidity in the water (Fig.3). Together with the extended time of contact of water with the external surface of pipeline connections, the values of this parameter increased. Turbidity in the water sourced at the initial point (Water Treatment Plant Zwada) reached approx. 0.23 NTU, whereas in the water after 10 hours of retention in the network it increased to $0.80 \mathrm{NTU}$. This value, despite being higher to that at the Water Treatment Plant, did not exceed 1 NTU, meeting thus the requirements outlined in the Directive [8].

Together with the increase of contact time of water with the distribution system, there was also an increase in general iron content in water samples. Water outflowing from the Water Treatment Plant in Zawada contained below 0.020 $\mathrm{mgFe} / \mathrm{dm}^{3}$, whereas at the P8 measuring point the iron content increased to 0.086 $\mathrm{mgFe} / \mathrm{dm}^{3}$. In neither of the measuring points did the iron content exceed the permissible value of $0.200 \mathrm{mgFe} / \mathrm{dm}^{3}$.

Due to biostability of water in the water supply network, it is also important to control the amount of organic compounds. Increase in the level of organic contamination of water can be a result of biofilm flushing from the walls of connections to the water stream, and the release of the products of metabolism of micro-organism inhabiting sedimentation. A wide variation of $\mathrm{COD}_{\mathrm{Mn}}$ values was noted in the tested water. In the water sourced at the Water Treatment Plant Zawada, the $\mathrm{COD}_{\mathrm{Mn}}$ value was approximately $2.17 \mathrm{mgO}_{2} / \mathrm{dm}^{3}$. At the measuring 
points $1,6 \mathrm{i} 7$ the $\mathrm{COD}_{\mathrm{Mn}}$ values ranged from $0.2 \mathrm{mgO}_{2} / \mathrm{dm}^{3}$ to $0.5 \mathrm{mgO}_{2} / \mathrm{dm}^{3}$. Greater values of this parameter were noted at points 2, 3, 4, 5 and 8: from $2.60 \mathrm{mgO} / \mathrm{dm}^{3}$ to $4 \mathrm{mgO}_{2} / \mathrm{dm}^{3}$. In all of the tested water sample, oxidasability fell into the permissible range specified in the Minster Directive [8] and did not exceed $5 \mathrm{mgO}_{2} / \mathrm{dm}^{3}$.

In order to evaluate the relation of the quality parameters of the water in the distribution system, a correlation coefficient was determined (Fig. 4). On the basis of the equations it could be assumed that changes in turbidity and colouration values are closely related to the general iron content in the water.

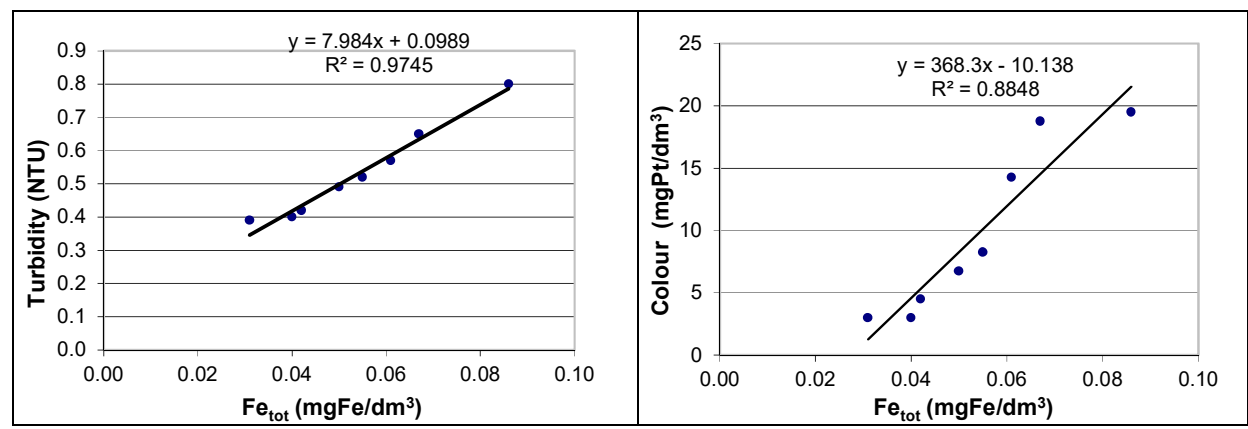

Fig. 4. Dependence of turbidity and colour increase on total iron concentration

The results analysis showed that despite the fact that the water introduced into the city network of Zielona Góra meets the quality parameters included in the Directive of the Health Minister, at the stage of further distribution occur problems related to secondary water contamination. Oversized system of distribution and diameter of pipelines causes insufficient use of water network's capacity. Thus, the related extension of retention time and hence extended contact of water with network's pipelines leads to deterioration of this quality. Unstable hydraulic parameters of work resulting from a significant unevenness of water distribution in the system also play a significant role in usage of disinfecting agent which quickly runs out which ten leads to a fast growth of micro-organisms in the network.

It was shown that values of colouring, turbidity and iron content increase together with the distance of the tested measuring points from the Water Treatment Plant in Zawada. The greatest increase of physiochemical parameters was noted in water samples sourced at the so-called "network ends" in measuring point 7 and 8 located in Kiełpin and Jarogniewice. This was affected by the long retention time of the water in distribution system, low velocity of flow and a high variability of daily intake.

The extended water flow time in the water supply network can cause diminishing of chloride. Water stagnation or a slow flow in the network contributes to 
corrosion and sedimentation of the products thereof in the pipelines. Long water flow periods in the water supply network also cause increase of concentration of disinfection by-products and decrease of chloride concentration.

\section{CONCLUSIONS}

When evaluating the test results, the following conclusions can be formulated:

- The results obtained signify a good effectiveness of water treatment at the Zawada Water Treatment Plant. The thresholds of permissible values in accordance with the Directive of the Health Minister were not exceeded.

- Together with the increase of distance of measuring points from the Water Treatment Plant in Zawada, the following parameters increased: turbidity, colouration, and iron content.

- Retention time and water distribution are the most significant factors in the network contributing to deterioration of water quality at measuring points.

- Deterioration of water quality is caused by prolong retention of water in the network, and thus by a longer contact time of water with the pipelines.

\section{REFERENCES}

1. Boryczko, K and Tchórzewska-Cieślak, B 2014. Analysis of risk of failure in water main pipe network and of delivering poor quality water. Environment Protection Engineering 40, 77-92.

2. Douterelo, I, Husband, S and Boxall, JB 2014. The bacteriological composition of biomass recovered by flushing an operational drinking water distribution system. Water Research 54, 100-114.

3. Kowal, AL 2003. Przyczyny $i$ zapobieganie zmianom jakości wody w systemach wodociagowych. Czasopismo Ochrony Środowiska. Gliwice: Politechnika Śląska.

4. Kowal, AL and Świderska-Bróż, M 2009. Oczyszczanie wody. Warszawa, PWN.

5. Krupińska, I 2012. Suitability of coagulation for treatment of groundwater. Rocznik Ochrona Środowiska 14, 491-501.

6. Olsińska, U and Skibińska, K 2007. Modelowanie zmian jakości wody w systemie dystrybucji. Czasopismo Ochrony Środowiska. Gliwice: Politechnika Śląska.

7. Płuciennik-Koropczuk, E and Kumanowska, P 2018. Chemical stability of water in the water supply network - preliminary research. Civil and Enviromental Engineering Reports 28, 079-089.

8. Regulation of the Minister of Health on quality requirements for water intended for human consumption, Journal of Laws 2017 item 2294. 
9. Świderska-Bróż, M and Wolska, M 2006. Główne przyczyny wtórnego zanieczyszczenia wody w systemie dystrybucji. Ochrona Środowiska 28, 29-34.

10. World Health Organization 2014. Water safety in distribution systems.

Available from

https://apps.who.int/iris/bitstream/handle/10665/204422/9789241548892_en

g.pdf;jsessionid $=52$ A1FDCDE5FA9164B14F59706F2938C3? sequence $=1$

\section{ZMIANY PARAMETRÓW FIZYKO-CHEMICZNYCH WODY W SIECI WODOCIĄGOWEJ W ZIELONEJ GÓRZE}

\section{Streszczenie}

$\mathrm{W}$ artykule przedstawiono zmiany parametrów fizyko-chemicznych $\mathrm{w}$ sieci wodociągowej w Zielonej Górze. Na podstawie uzyskanych wyników badań określono wpływ przetrzymania wody w sieci wodociągowej na jej jakość w punktach pomiarowych zlokalizowanych na terenie Zielonej Góry.

Wykazano, że wraz ze wzrostem odległości punktów pomiarowych od Stacji Uzdatniania Wody wzrastały wartości stężeń, głównie żelaza, mętności i barwy. Analizując wyniki stwierdzono, że czas przetrzymania oraz rozbiory wody w sieci są najistotniejszymi czynnikami powodującymi pogorszenie jakości wody w punktach pomiarowych.

Słowa kluczowe: jakość wody, wtórne zanieczyszczenie wody w sieci wodociągowej, system dystrybucji wody

Editor received the manuscript: 11.12.2018 